mr Jelena Drvendžija

Narodna banka Srbije jelena.drvendzija@nbs.rs
Prevod obezbedio autor

\title{
Rezime
}

TVRDA KORA ILI GORKA KOŠTICA

- ZAGONETKA DEFINISANJA FINANSIJSKE STABILNOSTI

Na međunarodnom i nacionalnim nivoima u poslednje vreme dolazi do ubrzanog razvoja nove oblasti javne politike, a to je makroprudencijalna politika. Njen cilj je da doprinese sprečavanju nastanka i otklanjanju ili ublažavanju sistemskih rizika u finansijskom sistemu i postizanju i održavanju finansijske stabilnosti. U literaturi ne postoji jedinstvena opšteprihvaćena definicija finansijske stabilnosti. Primećuje se da su definicije - korišćene u prošlosti bile daleko opštije i razuđenije, i da kako vreme prolazi, postaju sve preciznije. Ovo je posledica kompleksne prirode finansijskih sistema i mnoštva faktora koji utiču na njihovu stabilnost. Takođe, ni u evropskom zakonodavstvu, ni u nacionalnoj regulativi u Srbiji, ne definiše se eksplicitno na šta se tačno misli kada se govori o stabilnosti finansijskog sistema. Definicija finansijske stabilnosti koju je prihvatila Narodna banka Srbije u prvi plan stavlja funkcije koje treba da obavlja finansijski sistem, što odgovara širem pristupu finansijskoj stabilnosti.

Ključne reči: finansijska stabilnost, finansijski sistem, definicija, makroprudencijalna politika, sistemski rizik, finansijska infrastruktura, finansijska neravnoteža, finansijski šokovi, centralna banka

JEL: E52, E58, G28 


\section{THICK SKIN OR BITTER PILL - THE CHALLENGE OF DEFINING FINANCIAL STABILITY}

\section{Summary}

At the international and national levels we have recently witnessed an accelerated growth in the new field of public policy, i.e. macroprudential policy. Its goal is to help prevent the occurrence of, or eliminate and mitigate systemic risks in the financial system, thereby achieving and maintaining financial stability. Reference literature does not offer a uniform, generally accepted definition of financial stability. It may be observed that the definitions applied in the past used to be substantially broader and more diverse, having become increasingly precise over time. This has been the result of the complex nature of financial systems and the plethora of factors affecting their stability. Moreover, neither the European legislation nor the national regulations in Serbia explicitly define what is being referred to by the financial system's stability. The definition of financial stability accepted by the National Bank of Serbia focuses on the functions that the financial system should perform, which corresponds to the broader approach to financial stability.

Keywords: financial stability, financial system, definition, macroprudential policy, systemic risk, financial infrastructure, financial imbalance, financial shocks, central bank

JEL: E52, E58, G28

Paper received: 05.09.2014

Approved for publishing: 22.06.2015 


\section{Uvod}

Jedno je jasno: stabilnost finansijskog sistema podržava ekonomski razvoj obavljajući važne funkcije kao što su: kreditne i usluge štednje, transformacija štednje $\mathrm{u}$ investicije, usluge plaćanja i pružanje zaštite od rizika. Sa druge strane, finansijske krize koje otežavaju finansijsko posredovanje imaju značajne posledice na pad proizvodnje i zaposlenosti.

Takođe je jasno da finansijske krize koje su neprijatelj stabilnosti mogu nastati iz različitih razloga. Da pogledamo neke od najčešćih uzroka kriza. Jedan mogući uzrok je međusobno slično ponašanje finansijskih institucija u situacijama promena ekonomske perspektive. Tako, na primer, pristup banaka kreditnom tržištu zavisi od vrednosti kolaterala i percepcije rizika. Periodi koji su prethodili finansijskoj krizi bili su karakteristični po eksplozivnom rastu cena nekretnina i drugih oblika imovine i visokom kreditnom rastu. Sa pogoršanjem ekonomskih kretanja, vrednost kolaterala pada, a kao posledica toga menja se i pristup banaka tržištu kredita. Smanjenje ponude kredita deluje kao dobar potez sa aspekta individualne finansijske institucije, međutim, ako mnoge finansijske institucije $\mathrm{u}$ isto vreme smanje kreditnu aktivnost, to pojačava procikličnost $\mathrm{u}$ sistemu.

Drugi razlog može biti povezanost među institucijama, na primer, preko međubankarskog tržišta. Sa sve većim oslanjanjem na međubankarsko tržište, finansijski sektor postaje sve više umrežen. U takvim uslovima postoji povećan rizik da se teškoće $u$ jednoj instituciji mogu preneti na ostatak sistema. Takođe, ako institucije smanje svoju međusobnu izloženost nakon šoka, to može smanjiti likvidnost sistema kao celine.

Treći razlog bi mogao biti koncentracija rizika u nekoj važnoj finansijskoj instituciji. Krediti odobreni od strane jedne jedine institucije mogu biti takvog obima da nije moguće njihovo brzo supstituisanje kreditima drugih, tako da dolazi do smanjenja ukupne kreditne aktivnosti. Slično, kako se preko takvih institucija obavlja veliki deo platnog prometa, nije moguće da druge institucije $u$ kratkom roku preuzmu ove aktivnosti, što može dovesti do problema u funkcionisanju platnog sistema i nepovoljnog uticaja na likvidnost. Ovako važne institucije se zovu 'sistemski značajne finansijske institucije' što znači da čitava ekonomija može biti pogođena ukoliko se sistemski značajna finansijska institucija nađe u problemu.

Sve ove iskustvom potvrđene činjenice uticale su na to da na međunarodnom i nacionalnim nivoima dođe do ubrzanog razvoj nove oblasti javne politike, makroprudencijalne politike. Cilj ove politike je da u budućnosti doprinese sprečavanju nastanka i otklanjanju i ublažavanju sistemskih rizika u finansijskom sistemu. Ovo se može postići, na primer, stvaranjem dodatnih zaštitnih slojeva kapitala i likvidnosti u dobrim vremenima. Ako se ove aktivnosti ne sprovedu u dobrim vremenima, sa materijalizacijom rizika prostor za akciju se sužava. Nasuprot tome, preduzimanje akcija, na primer rast kapaciteta za apsorpciju gubitaka za vreme ekspanzije, osiguraće bolju poziciju čak iako ne bude moguće da se kriza izbegne. Drugim rečima, uloga makroprudencijalne politike trebalo bi da bude dopuna, a ne zamena, drugih makroekonomskih politika, kao što su fiskalna i monetarna, kako bi ponašanje finansijskog sistema bilo više u skladu sa interesima društva.

\section{Vrste definicija finansijske stabilnosti}

Iako doprinos očuvanju finansijske stabilnosti predstavlja važan cilj centralnih banaka, ipak, ni u nacionalnoj regulativi u Srbiji, ni u evropskom zakonodavstvu ne definiše se eksplicitno na šta se tačno misli kada se govori o stabilnosti finansijskog sistema. U literaturi ne postoji jedinstvena opšteprihvaćena definicija finansijske stabilnosti (Schinasi, 2004). Ovo je posledica kompleksne prirode finansijskih sistema i mnoštva faktora koji utiču na njegovu stabilnost. Takođe, primećuje se da su definicije koje su korišćene u prošlosti bile daleko opštije i razuđenije, i da kako vreme prolazi, postaju sve preciznije i eksplicitnije.

U mnoštvu definicija koje se mogu naći u literaturi, izdvajaju su dva pristupa u definisanju stabilnosti finansijskog sistema. Prvi pristup se oslanja na nabrajanje osobina stabilnog finansijskog sistema kao i funkcije koje on mora 


\section{Introduction}

One thing is clear: the financial system's stability supports economic development by performing essential functions like lending and savings services, transformation of savings into investments, payment services and risk protection. On the other hand, financial crises aggravating financial intermediation have significant consequences when it comes to declines in production and employment.

It is also clear that financial crises, as threats to stability, may occur from various reasons. Let us recall some of the most frequent causes of crises. One of the potential causes is the similar behavior of financial institutions in case of changed economic perspective. Thus, for instance, the access of banks to the credit market depends on the collateral value and risk perception. The periods preceding the financial crisis were characterized by the explosive growth of prices of real estate and other forms of property, accompanied by the high credit growth. As the economic trends deteriorate, the collateral value declines, as a consequence of which the access of banks to the credit market changes. Decreasing the loan offer seems like a good move from the aspect of an individual financial institution, yet, if many financial institutions reduce lending activity at the same time, it boosts procyclicality in the system.

Another reason might be the connectedness among institutions, for instance, via the interbank market. Given the increasing reliance on the interbank market, the financial sector has become intensely networked. Under

such circumstances there is a heightened risk of difficulties experienced by one institution being transferred to the rest of the system. Moreover, if the institutions reduce their mutual exposure after the shock, it might lower the liquidity of the system on the whole.

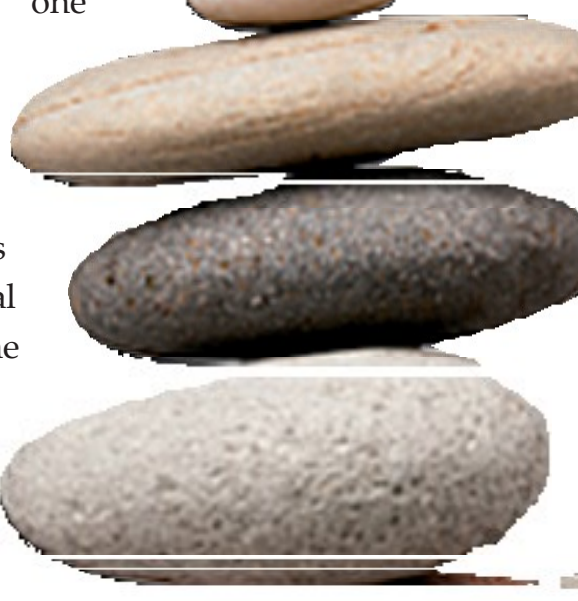

The third reason might be the concentration of risk in a very important financial institution. Loans granted by a single institution may be of such volume that it is impossible to quickly substitute them by the loans of other institutions, which leads to the reduction in total lending activity. Likewise, when a substantial portion of the payment turnover takes place via such institutions, it is impossible for other institutions to take these activities over within a short notice, which may cause certain problems in the functioning of the payment system and exert an adverse effect on liquidity. The institutions of such importance are called "systemically important financial institutions", meaning that the entire economy may be affected if a systemically important financial institution faces a problem.

All these facts confirmed through experience have contributed to the accelerated development of the new field in public policy, i.e. macroprudential policy, at the international and national levels. The goal of this policy is to help prevent the occurrence of, or eliminate and mitigate systemic risks in the financial system. This may be achieved, for instance, by generating additional protective layers of capital and liquidity in the good times. If these activities are not conducted in the good times, the room for manoeuvre narrows down with the materialization of risks. As opposed to that, undertaking relevant activities, for example, boosting the capacity for loss absorption during the expansion, ensures a better position even if the crisis is impossible to avoid. In other words, the role of macroprudential policy should not be to replace, but complement other macroeconomic policies, such as fiscal and monetary policy, so that the behavior of the financial system is more aligned with the interests of the society.

\section{Types of Definitions of Financial Stability}

Even though the contribution to the financial stability preservation is an important objective of central banks, neither the national 
biti u stanju da ostvaruje na zadovoljavajući način. Pored toga, ukazuje se na to da stabilnost sistema nije povezana sa statičnošću sistema, već se naglašava sposobnost sistema da apsorbuje šokove putem mehanizma samokorekcije, čime se umanjuje mogućnost finansijske krize (videti Szczepanska, 2008). Tako, na primer, Schinasi (2004) definiše finansijsku stabilnost kao sposobnost finansijskog sistema da: a) olakšava ne samo efikasnu alokaciju ekonomskih resursa $u$ prostoru i tokom vremena, već i ostale ekonomske procese (kao što su akumulacija bogatstva, ekonomski rast i društveno blagostanje); (b) oceni, vrednuje, alocira i upravlja finansijskim rizicima; i (c) obezbedi obavljanje ovih ključnih funkcija čak i u uslovima eksternih šokova ili akumuliranih neravnoteža. Praktična upotrebljivost ovakvih definicija nije ubedljiva, budući da se oslanjaju na koncepte koje je teško izmeriti.

Drugi pristup je daleko uži, i za razliku od prvog, koncentriše se na definisanje situacije ili stanja sistema u kome ne postoji kriza sistema. Tako, Allen \& Wood (2005) definišu finansijsku stabilnost kao suprotnost epizodama finansijske nestabilnosti. Ako se ekonomski akteri (npr. domaćinstva, kompanije ili javni sektor) suoče sa finansijskim pritiscima koji podrazumevaju dramatično i neočekivano smanjen pristup novcu, to će uticati na oštar pad potrošnje, i onda se ovakva epizoda može nazvati finansijskom krizom ili epizodom finansijske nestabilnosti. U okviru ovog pristupa neki autori ističu i određene poželjne aspekte u koje bi trebalo ući kako bi se unapredila sama definicija finansijske stabilnosti (videti W. A. Allen, \& G. Wood, 2005). Prvo, dobra definicija finansijske stabilnosti bi trebalo da bude povezana sa pojmom opšteg blagostanja. Drugo, stabilnost sistema bi morala biti nešto što je moguće primetiti (i izmeriti). Treće, finansijska stabilnost bi morala biti pod kontrolom i pod uticajem države. Četvrto, stabilnost finansijskog sistema bi morala biti odgovornost jasno određene institucije koja na raspolaganju ima oprobane i uticajne mere kojima reaguje $u$ ostvarivanju svojih zadataka. Peto, definicija finansijske stabilnosti bi morala biti dovoljno široka da uključi ne samo finansijske institucije već i druge institucije čije pokleknuće može ugroziti stabilnost sistema. Šesto, definicija finansijske stabilnosti po svojoj prirodi ne bi trebalo da bude uska niti isključiva.

Razmatrajući definicije finansijske stabilnosti centralnih banaka koje su članice Evropskog sistema centralnih banaka (engl. European System of Central Banks, ESCB) može se zaključiti da je većina njih samostalno razvila svoje definicije oslanjajući se najčešće na prvi, odnosno širi pristup određivanju finansijske stabilnosti (videti Smaga, 2013). Ove definicije se po pravilu objavljuju u Izveštaju o finansijskoj stabilnosti kao i u različitim javnim saopštenjima i izveštajima koje banke objavljuju (npr. na internet stranici centralne banke i sl.). U većini slučajeva centralne banke poistovećuju stabilnost finansijskog sistema sa neometanim funkcionisanjem finansijskog sistema, čak i ako se nađe $u$ ambijentu različitih ozbiljnijih šokova. Takođe, $\mathrm{u}$ jednoj komparativnoj analizi ovih definicija (Čihak, 2006) koja je prethodila izbijanju svetske finansijske krize, utvrđeno je da se centralne banke najčešće usredsređuju na poremećaje u obavljanju osnovnih funkcija, strukturnu ranjivost sistema, kao i negativan uticaj nestabilnosti finansijskog sistema na realnu ekonomiju. Slično istraživanje (IMF, 2011),
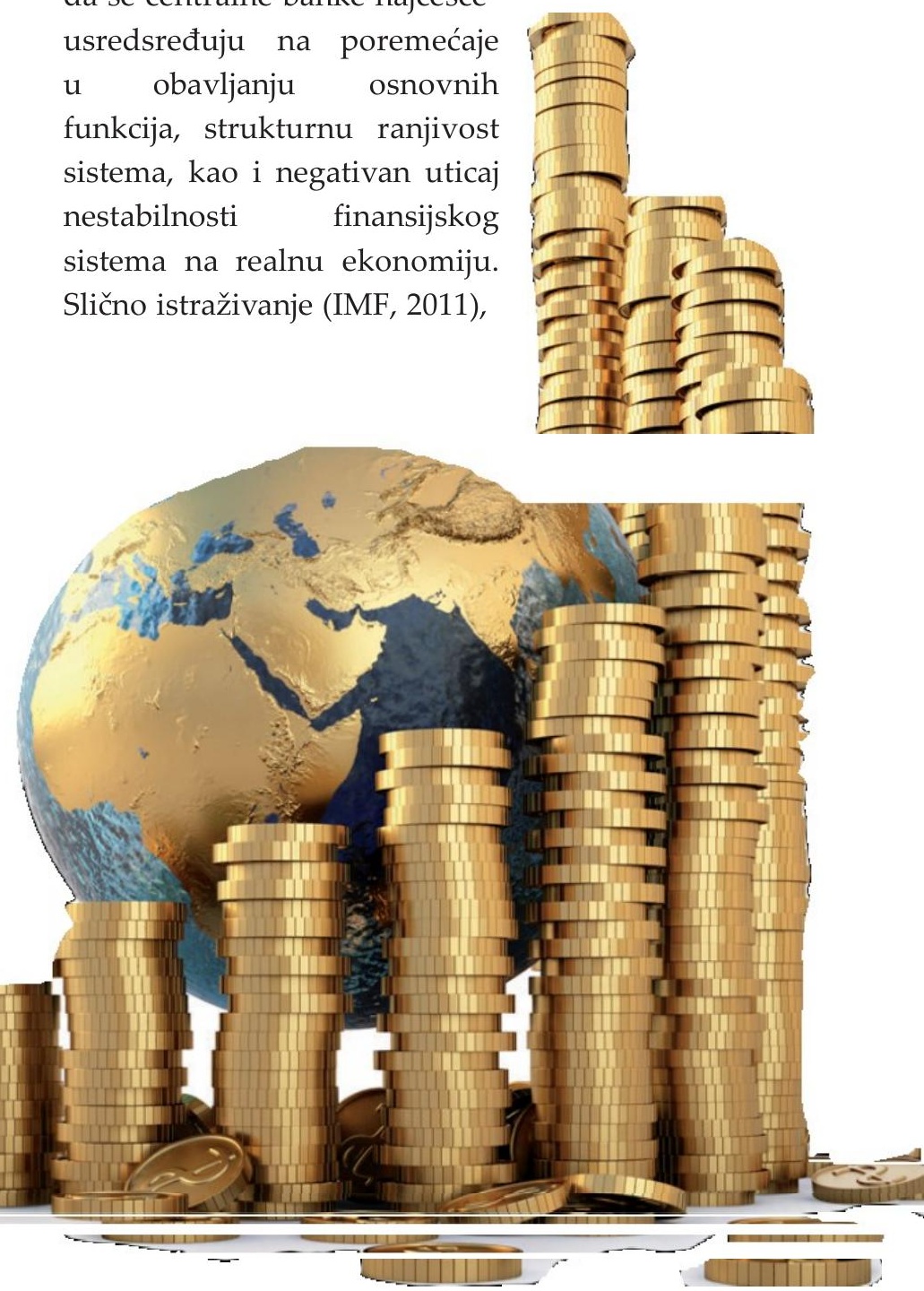
regulations in Serbia nor the European legislation explicitly define what exactly is being referred to by the financial system's stability. Reference literature does not offer a uniform, generally accepted definition of financial stability (Schinasi, 2004). This has been the result of the complex nature of financial systems and the plethora of factors affecting their stability. Also, it may be observed that the definitions applied in the past used to be substantially broader and more diverse, having become increasingly precise and explicit over time.

Among the many definitions that can be found in the reference literature, there are two approaches to defining the financial system's stability that stand out. The first approach relies on listing the characteristics of a stable financial system and the functions it must be able to perform in the satisfactory manner. Moreover, this approach indicates that the system's stability is not related to the system's static quality, and highlights the system's ability to absorb shocks by means of the auto-correction mechanism, which reduces the probability of a financial crisis (see Szczepanska, 2008). Thus, for instance, Schinasi (2004) defines financial stability as the financial system's ability to: a) facilitate not only the efficient allocation of economic resources in space and time, but also other economic processes (such as accumulation of wealth, economic growth and social welfare); b) assess, evaluate, allocate and manage financial risks; c) ensure that these key functions are performed even under the conditions of extreme shocks or accumulated imbalances. The practical usability of such definitions is not convincing, given that they rely on concepts difficult to quantify.

The second approach is much narrower, and, unlike the first one, it concentrates on defining the situation or the position of the system in which there is no systemic crisis. Thus, Allen \& Wood (2005) define financial stability as the opposite to the episodes of financial instability. If economic stakeholders (for instance, households, companies or the public sector) face certain financial pressures implying a dramatically and unexpectedly reduced access to money, it will result in a sharp decline in consumption, in which case such an episode can be referred to as a financial crisis or an episode of financial instability. Within this approach some authors emphasize certain desirable aspects that need to be tackled in order to improve the very definition of financial stability (see W. A. Allen \& G. Wood, 2005). First of all, a good definition of financial stability should be related to the term of general welfare. Secondly, the system's stability should be something that can be observed (and quantified). Thirdly, financial stability should be under the control and influence of the state. Fourth, the financial system's stability should be the responsibility of a clearly designated institution with tested and influential measures at its disposal, used for the purpose of responding in the process of achieving its tasks. Fifth, the definition of financial stability should be broad enough to include not only financial institutions but also other institutions whose failure may jeopardize the system's stability. Sixth, the definition of financial stability should be neither restricting nor exclusive.

After examining the definitions of financial stability outlined by the central banks which are members of the European System of Central Banks - ESCB, we may conclude that most of them independently developed their own definitions, typically relying on the first, i.e. the broadest approach to determining financial stability (see Smaga, 2013). These definitions are, as a rule, published in the Report on Financial Stability and in various public statements and reports published by banks (for instance on the webpage of the central bank, etc.). In most cases central banks identify the financial system's stability with the unhindered functioning of the financial system, even if it finds itself facing some serious shocks. Moreover, one comparative analysis of these definitions (Čihak, 2006) preceding the outbreak of the global financial crisis, established that the central banks most often focus on disturbances in performing the basic functions, the structural vulnerability of the system, and the negative impact of the financial system's instability to the real economy. A similar research (IMF, 2011), conducted by the IMF after the global financial crisis, showed that central banks in their definitions underline the importance of the system's resistance to shocks and the system's unhindered functioning despite the shocks. 
sprovedeno nakon svetske finansijske krize pod okriljem MMF-a, pokazalo je da centralne banke u svojim definicijama naglašavaju važnost otpornosti sistema na šokove i nesmetano funkcionisanje sistema uprkos šokovima.

\section{Definicija finansijske stabilnosti Narodne banke Srbije}

Slično drugim zemljama, u Zakonu o Narodnoj banci Srbije nije definisan pojam finansijske (ne)stabilnosti. Međutim, definicija (koja se vremenom razvijala) redovno se objavljuje $u$ Izveštaju o finansijskoj stabilnosti. U prvi mah pod finansijskom stabilnošću podrazumevala se "sposobnost svake komponente finansijskog sistema (finansijskog tržišta, finansijskih institucija i finansijske infrastrukture) da adekvatno odgovori na iznenadne rizike i te rizike apsorbuje" (videti Narodna banka Srbije, 2006). Nakon 2007. godine, finansijska stabilnost je opet dobila širu definiciju tako da je podrazumevala postojanje zdravih i stabilnih finansijskih institucija, čija otpornost na rizike inherentne finansijskom poslovanju i potrese iz okruženja omogućava efikasno sprovođenje finansijskog posredovanja i obezbeđuje stabilnost i poverenje u ukupan finansijski sistem pod nadzorom Narodne banke Srbije. Od 2011. finansijska stabilnost u definiciji Narodne banke Srbije podrazumeva da finansijski sistem (finansijski posrednici, finansijska tržišta i finansijska infrastruktura) omogućava efikasnu raspodelu finansijskih resursa i ostvarenje ključnih makroekonomskih funkcija, ne samo u normalnim uslovima, već i u uslovima finansijske neravnoteže ili potresa $u$ domaćem i međunarodnom okruženju.

\section{Funkcije finansijskog sistema}

Definicija finansijske stabilnosti koju je prihvatila Narodna banka Srbije u prvi plan stavlja funkcije koje treba da obavlja finansijski sistem, što odgovara širem pristupu finansijskoj stabilnosti. Za ovaj širi pristup karakteristično je isticanje dve osnovne funkcije (videti Schinasi, 2005) finansijskog sistema:

- Efikasno i nesmetano usmeravanje ekonomskih resursa (u geografskom smislu, kao i tokom vremena), što je zapravo finansijsko posredovanje,
- Identifikacija, ocena, usmeravanje i upravljanje finansijskim rizicima.

Ova podela ističe važnost finansijskog posredovanja putem koga stabilan finansijski sistem podržava privredni razvoj zemlje. U tom smislu ostaje otvoreno jedno važno pitanje - shvatanje pojma 'poremećaja ili šoka'. Na primer, da li se kreditna kriza može smatrati 'poremećajem' u funkcionisanju finansijskog sistema. Poznato je da povećana averzija prema riziku u periodima privredne recesije ili očekivano usporavanje privrednog rasta mogu prouzrokovati oštar pad kreditne aktivnosti. U takvim uslovima, mere monetarne politike i tržišne kamatne stope imaju ograničeni efekat na kreditnu ponudu. Čak i uslovima da postoji izražena kreditna tražnja i zadovoljavajuća kreditna sposobnost potencijalnih korisnika, banke vode restriktivnu kreditnu politiku, uključujući i potpuni prestanak odobravanja kredita. Ovakvo ponašanje banaka ukazuje na jasne poremećaje u funkcionisanju finansijskog sistema (posebno funkcije finansijskog posredovanja). Kreditna kriza se može, stoga, uslovno gledano razumeti kao poremećaj na tržištu. Možemo ići i korak dalje i reći da čak i da se radi o relativno ravnotežnom stanju, takva ravnoteža nije optimalna, naročito ako se sagleda iz perspektive specifične uloge koju bi efikasan finansijski sistem trebalo da igra $u$ privredi zemlje.

Međutim, finansijsko posredovanje nije jedina funkcija finansijskog sistema. Pravovremeno izvršavanje novčanih obaveza koje proističu iz ekonomske aktivnosti različitih učesnika, jednako je bitna funkcija. Centralna banka je $\mathrm{u}$ većini zemalja nosilac funkcije nadzora platnih sistema i sistema za poravnanje hartija od vrednosti. Narodnoj banci Srbije je zakonom povereno da uređuje, nadgleda i unapređuje nesmetano funkcionisanje platnog sistema, budući da bi, u slučaju poremećaja u njegovom funkcionisanju, izostalo poverenje javnosti u novac. Takođe, kada se ocenjuje stabilnost finansijskog sistema, ne može se isključiti mogućnost bankrotstva pojedinačnih institucija ili volatilnosti na finansijskom tržištu. Ove pojave predstavljaju prirodnu komponentu razvoja finansijskog sistema i finansijskih ciklusa. Ipak, problemi pojedinačnih institucija (ili grupa) u sistemu mogu ugroziti stabilnost 


\section{Definition of Financial Stability of the National Bank of Serbia}

Like in other countries, the Law on the National Bank of Serbia does not define the term of financial (in)stability. However, the definition (developing over time) is regularly published in the Report on Financial Stability. At first, financial stability referred to the "ability of each component of the financial system (financial market, financial institutions and financial infrastructure) to adequately respond to unexpected risks and to absorb them" (see National Bank of Serbia, 2006). After 2007, financial stability was once again defined more broadly, implying the existence of healthy and stable financial institutions whose resilience to the risks inherent to financial business and resistance to the shocks in the environment enables the efficient execution of financial intermediation and ensures stability and confidence in the overall financial system under the supervision of the National Bank of Serbia. Since 2011 financial stability according to the definition of the National Bank of Serbia has implied that the financial system (financial intermediaries, financial markets and financial structure) enables the efficient allocation of financial resources and the achievement of crucial macroeconomic functions, not only under normal circumstances, but also at the times of financial imbalance or turbulences in the domestic and international environment.

\section{Functions of the Financial System}

The definition of financial stability accepted by the National Bank of Serbia focuses on the functions that the financial system is supposed to perform, which corresponds to the broader approach to financial stability. What is characteristic for this broader approach is the emphasis on two basic functions (see Schinasi, 2005) of the financial system:

- Efficient and unhindered allocation of economic resources (in geographical and temporal terms), which actually refers to financial intermediation;

- Identification, assessment, diversification and management of financial risks.

This division pinpoints the significance of financial intermediation owing to which the stable financial system supports the economic development of the country. In this respect, there is one important issue that remains open - i.e. understanding the phenomenon of "disturbance or shock". For instance, can a credit crisis be considered a "disturbance" in the functioning of the financial system? As we know, increased risk aversion in the period of economic recession or expected deceleration of economic growth may cause a sharp decline in lending activity. Under such circumstances, the measures of monetary policy and market interest rates have a limited effect on credit supply. Even when there is a prominent credit demand and a satisfactory creditworthiness of potential users, banks are leading a restrictive credit policy, including the complete suspension in granting loans. Such behavior of banks indicates the clear disturbances in the financial system's functioning (especially the

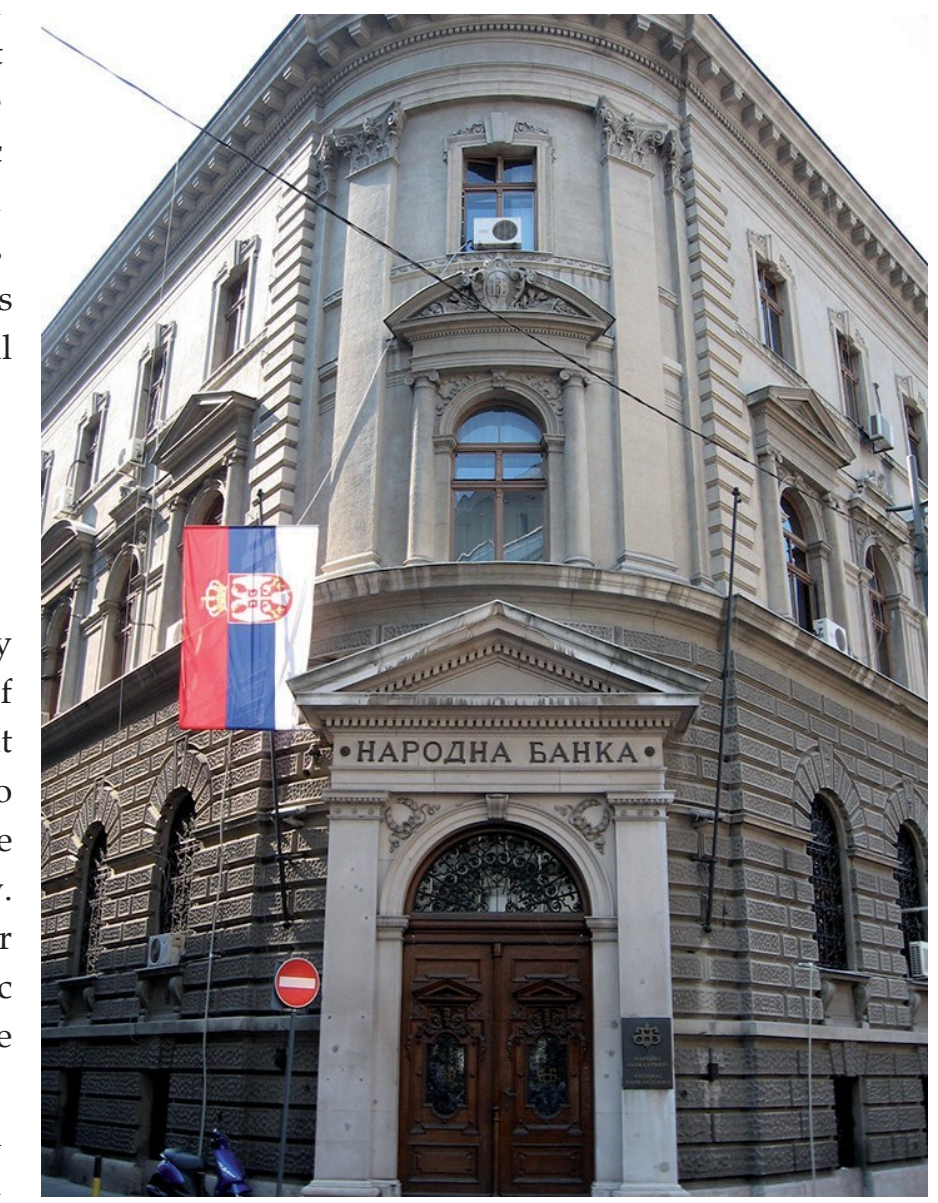


finansijskog sistema jedino ukoliko su toliko značajni da dovedu u pitanje funkcionisanje ukupnog finansijskog sistema kao celine.

$\mathrm{Na}$ nivou EU, utvrđen je institucionalni okvir makroprudencijalne politike formiranjem Evropskog odbora za sistemski rizik. Glavni zadatak ovog tela je sprečavanje nastanka, otklanjanje ili ublažavanje sistemskog rizika u EU. Ipak, makroprudencijalna politika pretežno će se voditi na nacionalnom nivou. Zato je Evropski odbor za sistemski rizik preporučio svim zemljama članicama da formiraju nacionalne institucionalne okvire makroprudencijalne politike, podrazumeva dodeljivanje odgovornosti od re đe n o j instituciji koja će imati na raspolaganju ne ophodne i n s trumente.

$\mathrm{Na}$ ovom mestu za trenutak ćemo zastati da se podsetimo da se sam pojam "makropudencijalni“ najverovatnije prvi put spominje u radu Kukovog komiteta (prethodnika sadašnjeg Bazelskog komiteta za superviziju banaka) još 1979. godine. Međutim, tek u najskorije vreme, od izbijanja poslednje finansijske krize, ovaj pojam se češće koristi u različitim dokumentima i stručnoj literaturi (o istoriji i značenju pojma "makroprudencijalni“ videti Piet Clement, 2010).

Da bi bilo reči o javnoj politici potrebno je da ona ima cilj, nosioca, instrumente i poznate transmisione mehanizme. Generalno gledano, krajnji cilj makroprudencijalne politike je doprinos očuvanju i jačanju finansijskog sistema kao celine ograničavanjem akumulacije (razvoja) sistemskog rizika (IMF, 2011). Nosilac makroprudencijalne politike može biti kolektivno telo $\mathrm{u}$ kome učestvuje više institucija ili jedna institucija. Međutim, u skladu sa preporukom Evropskog odbora za sistemski rizik o makroprudencijalnom mandatu (ESRB/2011/3, Preporuka B, odredba pod 3), u zemljama članicama EU nacionalne centralne banke treba da imaju vodeću ulogu u oblasti makroprudencijalne politike, pre svega zbog posedovanja stručnog znanja, i postojećih nadležnosti u oblasti finansijske stabilnosti. U pogledu instrumenata makroprudencijalne politike, ista preporuka (Preporuka C, ali odredba pod 4) naglašava potrebu da nosilac makroprudencijalne politike ima odgovarajuće instrumente kako bi ostvario zadati cilj. Instrumenti koji su raspoloživi za primenu makroprudencijalne politike utvrđeni su CRD IV paketom. Pošto se makroekonomski uslovi značajno $\mathrm{r} \mathrm{a} \mathrm{z} \mathrm{li} \mathrm{k} \mathrm{u} \mathrm{j} \mathrm{u}$ od zemlje do zemlje, neophodno je obezbediti odgovarajuću f l e k sibilnost makroprudencijalne politike na nacionalnom nivou. Takođe, u uslovima integrisanog finansijskog tržišta, međunarodna saradnja u oblasti formulisanja nacionalnih mera je veoma važna $\mathrm{i} u$ tom smislu će Evropski odbor za sistemski rizik imati i važnu ulogu koordinatora.

Razvoj delotvorne makroprudencijalne politike uključuje:

- izradu strategije makroprudencijalne politike (utvrđivanje njenog institucionalnog okvira, odnosa sa postojećim politikama, definisanje krajnjeg, osnovnih i prelaznih ciljeva, definisanje instrumenata za realizaciju ciljeva, poznavanje transmisionih mehanizama i utvrđivanje načina donošenja odluka);

- razvoj komunikacione strategije;

- obezbeđenje adekvatne koordinacije sa mikroprudencijalnom i monetarnom politikom;

- obezbeđenje adekvatne koordinacije sa makroprudencijalnim institucijama u EU, uključujući i Evropski odbor za sistemski rizik; 
function of financial intermediation). A credit crisis can, therefore, conditionally speaking be understood as a disturbance at the market. We can go a step further and say that, even if it were a state of relative equilibrium, this equilibrium would not be optimal, particularly from the perspective of the specific role that the efficient financial system should play in the country's economy.

However, financial intermediation is not the only function of the financial system. A timely settlement of monetary liabilities arising from economic activity of various participants is an equally important function. In most countries the central bank performs the function of supervising payment systems and systems for securities settlement. The National Bank of Serbia has been entrusted by the law with organizing, supervising and upgrading the unhindered functioning of the payment system, given that, in case of its disturbed functioning, the public's confidence in the national money would be lost. Moreover, when assessing the stability of the financial system, one cannot exclude the possibility of individual institutions' bankruptcy or financial market volatility. These phenomena are the natural component in the development of financial system and financial cycles. Nevertheless, the problems of certain institutions (or groups) in the system may jeopardize the stability of the financial system only if they are so substantial to bring into question the functioning of the financial system as a whole.

The EU established an institutional framework for macroprudential policy by forming the European Systemic Risk Board. The main task of this body is to prevent the occurrence of, eliminate or mitigate systemic risk in the EU. Still, macroprudential policy will predominantly be led at the national level. This is why the European Systemic Risk Board recommended to all member states to form their national institutional frameworks for macroprudential policy, implying the assignment of responsibility to a certain institution which will have the required instruments at its disposal. Here we will make a small digression to recall that the term "macroprudential" itself was probably mentioned for the first time during the activities of the Cook's Committee (the forerunner of the present Basel Committee on Banking Supervision) back in 1979. However, it is only recently, since the outbreak of the latest financial crisis, that this term has been used more often in various documents and professional literature (on the history and meaning of the term "macroprudential" see Piet Clement, 2010).

In order for a public policy to be valid, it must have a goal, a carrier, the instruments and recognized transmission mechanisms. Generally speaking, the ultimate goal of macroprudential policy is to contribute to the preservation and strengthening of the financial system as a whole, by limiting the accumulation (and development) of systemic risks (IMF, 2011). The carrier of macroprudential policy can be a collective body gathering several institutions or a single institution. However, in line with the recommendation of the European Systemic Risk Board concerning macroprudential mandate (ESRB/2011/3, Recommendation B, Provision no. 3), in the EU member states the national central banks should play the leading role in the field of macroprudential policy, first of all due to their expert knowledge on the subject, and the existing competencies in terms of financial stability. When it comes to the instruments of macroprudential policy, the same recommendation (Recommendation C, Provision no. 4) underlines how necessary it is for the macroprudential policy carrier to have the appropriate instruments in order to achieve the set goal. The instruments available for the implementation of macroprudential policy have been established by the CRD IV package. Given that macroeconomic conditions substantially differ in various countries, it is necessary to ensure the appropriate flexibility of macroprudential policy at the national level. Also, in the environment of integrated financial markets, international cooperation in formulating national measures is very important, in which respect the European Systemic Risk Board will play a significant role as the coordinator.

The development of efficient macroprudential policy involves the following aspects:

- Preparing the macroprudential policy 
- poboljšanje raspoloživosti, kvaliteta i uporedivosti podataka koji se koriste za makroprudencijalnu analizu;

- permanentno razvijanje makroprudencijalne politike, u skladu sa iskustvom koje se bude sticalo u domaćoj i uporednoj praksi.

Razvoj makroprudencijalne politike važan je i sa aspekta pregovora o članstvu Republike Srbije u Evropskoj uniji koji su otvoreni u januaru 2014. godine. Primena acquis communautaire $\mathrm{u}$ oblasti makroprudencijalne politike predmet je pregovora u "Poglavlju 17" koje se odnosi na ekonomska i monetarna pitanja. Izmene i dopune propisa kojima će se izvršiti usklađivanje sa navedenim aktima biće usvojene najkasnije šest meseci pre nego što Narodna banka Srbije postane deo Evropskog sistema centralnih banaka, odnosno Republika Srbija postane član Evropske unije.

Narodna banka Srbije ima značajno iskustvo u primeni ne samo makroprudencijalnih, već i mikroprudencijalnih i instrumenata monetarne politike da bi se ostvarili makroprudencijalni ciljevi, iako za sada formalno nije ustanovljena makroprudencijalna politika. Bez obzira na ovu činjenicu, neophodno je uspostaviti čvršći režim makroprudencijalnog nadzora.

\section{Zaključak}

Mandat centralne banke da doprinosi finansijskoj stabilnosti ustanovljen je $u$ nacionalnom zakonodavstvu, i to je u skladu sa regulativom Evropske unije. Pored osnovnog cilja centralne banke koji se odnosi na održavanje cenovne stabilnosti, ona doprinosi i očuvanju stabilnosti nacionalnog finansijskog sistema. Radi se, dakle, o dodatnom cilju, koji može, ali i ne mora biti podređen osnovnom. Ukoliko je dodatni cilj podređen osnovnom (što je slučaj u Srbiji), to znači da se u slučaju postojanja konflikta između ciljeva, prednost daje osnovnom cilju. Najnoviji talas promena Zakona o centralnim bankama, insistira na nepodređenosti dopunskog cilja osnovnom (npr. u Češkoj, Mađarskoj, Poljskoj, Novom Zelandu).
U Srbiji, slično mnogim drugim evropskim zemljama, centralna banka (Narodna banka Srbije - NBS) ima zakonski mandat za delovanje na polju finansijske stabilnosti. Zakon o Narodnoj banci Srbije iz 2003. godine (,Službeni glasnik RS“, br. 72/2003), u čl. 3, Narodnoj banci Srbije stavlja eksplicitno u nadležnost doprinos očuvanju finansijske stabilnosti, pored osnovnog cilja (postizanje i održavanje stabilnosti cena). Izmenama i dopunama Zakona o Narodnoj banci Srbije iz 2010. godine, Narodnoj banci Srbije je poveren doprinos očuvanju i jačanju stabilnosti finansijskog sistema. Konkretno, članom 3. Zakona o Narodnoj banci Srbije („Službeni glasnik RS“, br. 72/2003, 55/2004 i 44/2010) propisano je da Narodna banka Srbije, ne dovodeći u pitanje ostvarivanje svog osnovnog cilja - održavanja stabilnosti cena, doprinosi očuvanju i jačanju stabilnosti finansijskog sistema. Na ovaj način je mandat Narodne banke Srbije, pored doprinosa očuvanju stabilnosti finansijskog sistema, kao što je bilo predviđeno ranijim tekstom zakona, proširen i na doprinos jačanju te stabilnosti. Ipak, očuvanje i jačanje celokupnog finansijskog sistema obuhvata širok spektar politika (i instrumenata) koje ne mogu biti u formalnoj nadležnosti isključivo centralne banke. Stabilnost finansijskog sistema kao celine zavisi od brojnih aktivnosti koje su u nadležnosti različitih institucija i nijedna pojedinačna institucija ne može biti odgovorna za očuvanje te stabilnosti u celini, tako da koordinirano delovanje svih relevantnih institucija i priprema jedinstvenog okvira makroprudencijalne politike postaju neophodnost dana.

Danas možemo reći da nam je još jedna stvar jasna: stabilan finansijski sistem mora biti u stanju da apsorbuje različite šokove, nakon čega se, usled delovanja tržišnih sila ili pak manje intervencije nadležnih institucija, ponovo uspostavlja nova ravnoteža u sistemu. Takođe je jasno da bi postizanju i održavanju ovog cilja trebalo da budu posvećeni svi učesnici u finansijskom sistemu. 


\section{Literatura / References}

1. Abazomi A. Alawode, Mihammed Al Sadek (2008), What is Financial Stability, Central Bank of Bahrain, Financial Stability Paper Series No 1, March 2008.

2. Acouch Mohamed, Abdessamad Saidi, Farano Zakaria (2012), Financial Stability: Definitions, Theoretical Foundations and Roles of the Central Banks, International Research Journal of Finance and Economics No 84.

3. Allen, A. \& Wood, G. (2005), Defining and Achieving Financial Stability, Financial Markets Group, Special Paper No 160, London School of Economics.

4. Čihak, M. (2006), How Do Central Banks Write on Financial Stability? , IMF Working Paper, WP/06/163.

5. Czech National Bank (2010-2011), Financial Stability, Systemic Risk and Macroprudential Policy, FSR.

6. Deutsche Bundesbank (2013), Macroprudential Oversight in Germany: Framework, Institutions and Tools, Monthly Report, April 2013.

7. European Systemic Risk Board (2011/3), Recommendation of the European Systemic Risk Board of 22 December 2011 on the macroprudential mandate of national authorities (ESRB/2011/3) (Official Journal C 41/1, 14/02/2012) CELEX $32012 Y 0214$ (01).

8. European Systemic Risk Board (2013/1), Recommendation of the European Systemic Risk Board of 4 April 2013 on intermediate objectives and instruments of macro-prudential policy (ESRB/2013/1) (Official Journal C 170/1, 15/06/2013) CELEX 32013 Y0615 (01).

9. European Systemic Risk Board (2014), Flagship Report on Macro-prudential Policy in the Banking Sector, March 2014.
10. European Systemic Risk Board (2014), Handbook on Operationalizing Macroprudential Policy in the Banking Sector.

11. Garry J. Schinasi (2004), Defining Financial Stability, IMF Working Paper, WP/04/187.

12. Haldane, Andrew (2012), Macroprudential Policies - When and how to use them, presented at "Rethinking Macro Policy II: First Steps and Early Lessons", IMF Conference, Wahington, April 2012.

13. Iwanicz-Drozdowska (2011), Definicje i determinanty stabilności finansowej, Bank i Kredyt, (dodatek edukacyjny) No 1/2011.

14. Schinasi, J. G., (2004), Defining Financial Stability, 2004, IMF Working Paper, WP/04/187, IMF.

15. Jan Frait, Zlatuše Komárková (2011), Financial stability, systemic risk and macroprudential policy, Czech National Bank, Financial Stability Report 2010/2011.

16. Narodna banka Srbije (2006), Godišnji izveštaj o stanju u finansijskom sistemu Srbije za 2006. godinu.

17. National Bank of Poland (2011), Financial Stability A-Z.

18. National Bank of Poland (2013), Financial System Stability - Concept and Definitions, Financial Stability Report.

19. Piet Clement (2010), The Term 'Macroprudential': Origin and Evolution, BIS Quarterly Review, March.

20. Smaga, P. (2013), Istota stabilnosci finaniowej, Studia i Prace Kolegium Zarzadzania i Finansow, Zeszyt Naukowy 124, Warshaw School of Economics.

21. Szczepanska, O. (2008), Stabilnosc finansowa jako cel banku centralnego, Wydawnictwo Naukowe SHOLAR. 
Law on Central Banks insists that the additional goal remains non-subordinate to the main one (for instance, in Czech Republic, Hungary, Poland, New Zealand).

In Serbia, like in many other European countries, the central bank (i.e. the National Bank of Serbia - NBS) has the legal mandate to act in the field of financial stability. The Law on the National Bank of Serbia from 2003 ("Official Gazette of the RS", no. 72/2003), in its Article 3, explicitly grants to the National Bank of Serbia the competence to contribute to the preservation of financial stability, in addition to its main goal (i.e. to achieve and maintain the stability of prices). According to the amendments to the Law on the National Bank from 2010, the National Bank of Serbia was entrusted with contributing to the preservation and strengthening of the financial system's stability. In particular, Article 3 of the Law on the National Bank of Serbia ("Official Gazette of the RS", no. 72/2003, 55/2004, and 44/2010) prescribes that the National Bank of Serbia, without jeopardizing the achievement of its main goal - i.e. the maintenance of price stability, shall contribute to the preservation and strengthening of the financial system's stability. Thus, the mandate of the National
Bank of Serbia, in addition to contributing to the preservation of the financial system's stability, as was prescribed by the earlier wording of the Law, has been broadened to include the contribution to this stability's strengthening. Still, the preservation and strengthening of the overall financial system includes a wide range of policies (and instruments) which cannot be under the formal jurisdiction of the central bank exclusively. Stability of the financial system on the whole depends on numerous activities which are under the jurisdiction of various institutions, and no individual institution can be entirely responsible for preserving this stability overall. Hence, it is necessary to achieve coordinated action of all relevant institutions and to prepare a uniform macroprudential policy framework.

Today we can say that another thing is clear: a stable financial system must be able to absorb all kinds of shocks, after which, due to the effect of market forces or a smaller intervention by the competent institutions, a new equilibrium is restored in the system. It is also clear that all stakeholders in the financial system need to be devoted to the achievement and maintenance of this goal. 